\title{
Enaction of Chapter VII of the Insurance Distribution Directive: What Can Member States Learn from the Enforcement Failures of the United States?
}

\author{
Kathleen M. Defever
}

\section{Introduction}

We are entering a new era of insurance regulation, in which our economic systems continue to grow larger and more profitable, and the authorities tasked with regulation of insurance markets are facing more intense, complex challenges. Most people would agree that an overall increased prosperity is positive and beneficial for society-but in a capitalistic, free market-based system, when more wealth is created and concentrated, this creates more acute market powers. Market power per se is not problematic, but market leaders need the guidance of governmental authorities in order to ensure that their choices and methods geared toward profit maximization are not also causing damage to their own societies. With governmental regulation, economic activity can be guided with the aim of helping all of society to be richer and happier, as a whole.

In the European Union, insurance regulation was recently increased when the Commission issued the Insurance Distribution Directive (IDD), to regulate the methods in which insurance intermediaries are allowed to sell insurance products to consumers. ${ }^{1}$ The IDD marks a significant progression toward increased uniformity of regulation across the entire European Union, and is more far-reaching in terms of regulatory detail. The IDD requires very specific actions of every insurance intermediary engaged in commerce in the EU member states, and prescribes specific

\footnotetext{
${ }^{1}$ Directive (EU) 2016/97 of the European Parliament and of the Council of 20 January 2016 on insurance distribution (recast), Text with EEA relevance.
}

\author{
K. M. Defever $(\bowtie)$ \\ DePaul University College of Law, Chicago, IL, USA \\ University of Connecticut School of Law, Hartford, CT, USA \\ e-mail: kathleen@defeverlaw.com


punishments for infringements. In the United States, the current regulations applicable to intermediaries have been in place for several decades or more, so enough time has passed to gain insight into whether these regulations have been successful, and to what degree. We will particularly assess the enforcement regimes in the United States, and discuss their overall lack of effectiveness.

\section{Broad Landscape of the Unites States' Regulation of Insurance Intermediaries}

In the United States, insurance regulation is almost entirely the responsibility of the individual states. Typically, the U.S. Congress regulates all commerce which crosses state lines, and this would definitely include insurance sales. ${ }^{2}$ However, because individual states regulated insurance commerce for nearly a century before Congress contemplated federal regulation, it was decided that the states would be allowed to continue their regulatory regimes and Congress would only intervene when it was necessary. ${ }^{3}$ Since then, Congress has only intervened on a few topics of insurance, such as terrorism insurance, flood insurance, employee retirement plans, and group health and disability coverages.

Most insurance regulation originates with the individual state insurance commissioners, who collectively comprise the National Association of Insurance Commissioners (NAIC). The NAIC drafts the model insurance laws which are then typically adopted, in part or in full, by the individual states. However, there is no requirement that the states adopt these model laws, and no requirement that the adopted laws are enforced. NAIC model acts are merely advisory tools, and despite their careful drafting, they have had little success in achieving uniformity of American insurance laws.

The primary body of law applied to insurance intermediaries in the United States is the Producer Licensing Model Act (PLMA), authored by the NAIC and adopted in some form by 40 states. ${ }^{4}$ The Act is meant to govern "the qualification and procedures for the licensing of insurance producers," and "simplif[y] and organize some statutory language to improve efficiency... and reduce costs associated with issuing and renewing insurance licenses." The PLMA defines an insurance producer as "a person required to be licensed under the laws of this state to sell, solicit or negotiate insurance."

In part, the PLMA details recommended licensing procedures, supplies reasons for revocation or denial of licenses, addresses which types of paid commissions are

\footnotetext{
${ }^{2}$ Gibbons v. Ogden (1824); United States v. South-Eastern Underwriters Association (1944).

3، [N]o act of Congress shall be construed to invalidate, impair, or supersede any law enacted by any State for the purpose of regulating the business of insurance... unless such Act specifically relates to the business of insurance.”; 15 U.S.C. §1012(b).

${ }^{4}$ Producer Licensing Model Act (2005), National Association of Insurance Commissioners, found at: https://www.naic.org/store/free/MDL-218.pdf.

${ }^{5}$ Relevant material quoted from Section 1. Purpose and Scope, PLMA (2005).
} 
allowed, and outlines recommended compensation disclosures. While the PLMA does briefly address how violations of the Act may be handled by state insurance commissioners, it mostly leaves the details to the individual states. This will be addressed further in Sects. 4 and 5.

In the United States, legislatively-drafted insurance regulations like the PLMA are bolstered by the common law system, otherwise known as case law, or courtissued decisions. ${ }^{6}$ Ostensibly, where the legislators have failed, the courts can act as a "check and balance" and issue proclamations which bolster-or which put into question - the regulations. However, these two branches of government (legislative and judiciary) are only able to bolster and improve one another when each branch is working efficiently. As we will discuss, the current system of United States "checks and balances" is not operating efficiently and is unable to build and support the level of regulatory clarity and enforcement which is needed to sustain an optimally healthy economic environment for insurance intermediaries and their customers.

\section{Insurance Distribution Directive Overview}

The Insurance Distribution Directive is the successor of the Insurance Mediation Directive (IMD), ${ }^{8}$ and as such is wider in scope and more specific in commandment. The primary relevant objectives listed in the recitals are as follows-minimum harmonization among the Member States; increased consumer protection and better information provision for customers-including the creation of a standardized insurance product information document, comparable standards which bring consumers more predictability, analysis of the consumers "demands and needs" before sale, and provision of personalized advice for customer; ensuring the orderly pursuit of insurance business and fair treatment by regulatory authorities; creation of a single information point for registers of insurance intermediaries; coordination of Member State licensing provisions; establishment of out-of-court redress procedures; protection of consumers from intermediary conflicts of interest; transparency of intermediary remuneration; a new product development governance procedure ${ }^{9}$; and the provision of different methods of enforcement, including monetary sanctions and criminal sanctions.

\footnotetext{
${ }^{6}$ See Viscusi, Kip, Regulation through Litigation (2002) for more detailed discussion on this concept.

${ }^{7}$ Definition of U.S. concept of "checks and balances" can be found at: https://legaldictionary.net/ checks-and-balances/, last visited September 25, 2019.

${ }^{8}$ Directive (EU) 2002/92/EC of the European Parliament and of the Council of 9 December 2002 on insurance mediation.

${ }^{9}$ Notably, in the United States product oversight and governance is managed by the individual state insurance commissioners through entirely separate insurance codes which generally apply to insurance companies and their products-product oversight and governance is not addressed in the PLMA.
} 
The IDD is applicable to insurance and reinsurance distribution, which specifically is defined as the "activities of advising on, proposing, or carrying out other work preparatory to the conclusion of contracts of insurance, of concluding such contracts, or of assisting in the administration and performance of such contracts, in particular in the event of a claim, ${ }^{10}$ including the provision of information concerning one or more insurance contracts in accordance with criteria selected by customers through a website or other media... when the customer is able to directly or indirectly conclude an insurance contract." ${ }^{11}$ An insurance intermediary is defined as a natural or legal person who, for remuneration, pursues the activity of insurance distribution. $^{12}$

\section{Comparing the Producer Licensing Model Act with the Insurance Distribution Directive}

The most striking difference between the PLMA and the IDD is that the PMLA is written from the perspective of the individual U.S. state legislators and/or their insurance commissioner, so that the PLMA can be directly adopted by the individual states. Everything in the PLMA is merely a suggestion being made by an advisory body. The IDD, on the other hand, is a mandatory directive authored by the EU Commission, a legislative body with the authority to require the Member States to adopt legislation. Therefore, the language varies considerably.

\subsection{Organizational Requirements}

Chapter IV of the IDD lays out Organizational Requirements for the Member States. In Article 14, Member States are required to set up procedures for customers to register complaints about insurance distributors, and "in all cases, complainants shall receive replies." Further, Member States are required to ensure that an effective, impartial, and independent out-of-court redress procedure is available for the settlement of customer-intermediary disputes. ${ }^{13}$ There are no such requirements in the PLMA. However, most U.S. States have created an Office of the Insurance

\footnotetext{
${ }^{10}$ The addition of the language "in particular in the event of a claim" has been rightly criticized for creating confusion, as the insurance distribution directive is otherwise focused on the production and sales of insurance products, i.e. their distribution. The processing of insurance claims is an entirely separate undertaking from the sales and distribution of products and policies. See Pscheidl (2018), p. 208.

${ }^{11}$ IDD Article 2, 1. (1).

${ }^{12}$ IDD Article 2, 1. (3).

${ }^{13}$ IDD Article 15.
} 
Commissioner (or similar), and that office does handle consumer complaints. The process is entirely voluntary for the individual state officials, and there is no procedural guarantee that the complaint will receive a reply. Additionally, the U.S. states do not make out-of-court complaint and redress procedures available for settlement purposes, beyond the limited service they typically provide to register a complaint, notify the insurer or intermediary of the complaint, and then advise the customer on a course of action. This process is widely criticized as non-effective toward resolution, and correspondingly is seldom even initiated by consumers.

\subsection{Duties of Insurance Intermediaries/Producers}

Chapter V of the IDD delineates the information requirements for intermediaries, and the rules applicable to their business conduct. Section 12 of the PLMA lists prohibited actions which can lead to an insurance intermediary's license revocation and a civil penalty. Despite that the IDD language is written in a prescriptive manner and the PLMA is written in a proscriptive manner, there are some similarities.

Article 17 of the IDD requires that insurance distributors "always act honestly, fairly and professionally in accordance with the best interests of their customers." Section 12 A. (8) of the PLMA forbids an insurance producer from "using fraudulent, coercive, or dishonest practices, or demonstrating incompetence, untrustworthiness or financial irresponsibility in the conduct of business..." Notably while the IDD requires "professionalism," the PLMA forbids "incompetence, untrustworthiness or financial irresponsibility," which although differently described, seem to be similar standards. What is strikingly missing from the PLMA is the requirement that U.S. insurance intermediaries act "with the best interests of their customers," as is required of European intermediaries.

Another requirement present in the IDD that is glaringly absent from the PLMA is that marketing be "fair, clear, and not misleading." 14 This is a much stricter standard than the usual prohibition of fraud found in all U.S. common law. The EU appears to be requiring a shift toward "good behavior," or marketing that is more protective of the customer, while the U.S. is merely prohibiting "bad behavior". All of the 50 U.S. states have the unfettered ability to write stricter laws, since the PLMA is advisory and the federal government does not monitor insurance intermediaries. But, in reality, the average state struggles to enforce the basic PLMA provisions, much less create stricter regulations. ${ }^{15}$

The PLMA places only two restrictions on the remuneration of insurance producers-one, that a producer must be licensed in order to receive commissions, and two, that the producer must disclose a compensation agreement with an insurer if the

\footnotetext{
${ }^{14}$ IDD Art. 17, 2.

${ }^{15}$ This is based on the general knowledge and understanding of the author. Regulatory activities in a specific state may vary.
} 
producer is also receiving compensation from the customer. ${ }^{16}$ In contrast, the IDD mandates that Member States shall ensure that distributors and their employees are not remunerated in a way that conflicts with their duties to act in accordance with the best interest of their customers ${ }^{17}$; that they reveal business holdings that create conflicts $^{18}$; that they reveal whether advice is based on fair and personal analysis or not, or whether there is exclusivity with an insurance company ${ }^{19}$; and that they reveal the nature of remuneration received, i.e. fee, commission, or other, and the amount, and whether it ties to employee remuneration. ${ }^{20}$

Beyond these requirements, the IDD includes numerous other new regulations of the activities of insurance intermediaries that are not addressed in the PLMA. Briefly, the IDD now requires a product information document that supplies information to the customer in a comprehensible form which allows the customer to make an informed decision; when advice will be given by the insurance distributor, they must specify the demands and needs of the customer based on the information that the customer provides, and the contract proposed shall be consistent with these demands and needs, and the result of an analysis of a sufficiently large number of insurance contracts available on the market. ${ }^{21}$ In comparison to the sparse prohibitions of the PLMA, these IDD regulations are very detailed and specific. Additionally, the IDD now requires a product review process within each insurance distributor's company operations, and provides that sanctions shall apply to any infringements. ${ }^{22}$

\subsection{Sanctions, Penalties, and Other Measures}

Because the nature of the PMLA is advisory, specific sanctions are not prescribed as they are in the IDD. However, the PMLA does provide suggested penalties for violations of the duties of insurance producers within Section 12-" [t]he insurance commissioner may place on probation, suspend, revoke or refuse to issue or renew an insurance producer's license or may levy a civil penalty in accordance with [state law]." The PMLA clarifies that nothing in the Act prohibits the commissioner from releasing final, adjudicated actions to be open to public inspection. ${ }^{23}$ Section 19 further clarifies that individual states retain full authority for enforcement, reassuringly indicating "The insurance commissioner may, in accordance with [state law],

\footnotetext{
${ }^{16}$ PLMA Sect. 13 and Sect. 18.

${ }^{17}$ IDD Art. 17, 3.

${ }^{18}$ IDD Art. 19, 1. (a) and (b).

${ }^{19}$ IDD Art. 19, 1. (c).

${ }^{20}$ IDD Art. 19, 1. (d), (e), 2., and 4.

${ }^{21}$ IDD Art. 20.

${ }^{22}$ IDD Art. 25.; See also footnote 10.

${ }^{23}$ PLMA Sect. 15, F. (5).
} 
promulgate reasonable regulations as are necessary or proper to carry out the purposes of this Act."

Section VII of the IDD, titled "Sanctions and Other Measures," is far more exhaustive and detailed than the PMLA. At the outset, the Commission made it clear that Member States can keep their own criminal sanctions, as long as they provide notice to the Commission. ${ }^{24}$ This is similar to Section 19 of the PLMA, only American states do not need to report their regulations to the NAIC or any federal government body. Additionally, European Union Member States are required to publish sanctions when they are imposed ${ }^{25}$ - as opposed to the PLMA "allowance" that commissioners may make the sanctions public.

Where the IDD significantly departs from the PLMA is Article 33, 2. The Commission requires Member States to ensure that their competent authorities have the power to impose at least the following additional administrative sanctions and other measures: an order requiring the responsible person to cease the conduct and desist from a repetition; withdrawal of the insurance intermediary's registration; ban on certain management functions; and the imposition of particular sanctions. For a legal person, i.e. an insurance corporation, the maximum pecuniary sanctions are at least $€ 5$ mil or up to $5 \%$ of total annual turnover, or up to two times the amount of profits gained (or losses avoided) due to the breach. For a natural person, i.e. an individual intermediary, the maximum pecuniary sanctions are at least $€ 700,000$ or up to two times the amount of profits gained (or losses avoided) due to the breach. Then, in numeral 4 of Article 33, Member States are specifically allowed to have additional sanctions or other measures, and are allowed higher levels of administrative pecuniary sanctions than those provided in that same article. This leads one to question the use of the word "maximum" where Article 33 had already listed specific monetary penalties.

Article 34, titled "Effective Application of Sanctions and Other Measures," provides mandatory guidance to Member States applying sanctions, requiring that competent authorities shall take into account "all relevant circumstances, including where appropriate..."... the gravity and duration of the breach, the degree of responsibility of the responsible person, the financial strength of the responsible person, the importance of profits gained or losses avoided, the losses for customers, level of cooperation of the responsible person with authority, any measures taken to prevent repetition of breach, and any previous breaches. The IDD has taken a large step toward a significantly more strict, rules-based body of regulations that prescribes specific penalties, but the PMLA lacks any provisions that reach beyond the suggestion of a general "allowance" for state insurance commissioners to create their own penalty schemes.

\footnotetext{
${ }^{24}$ IDD Art. 31.

${ }^{25}$ And report them to EIOPA, Art. 32.
} 


\section{How the United States Enforces Insurance Intermediary Regulations}

As mentioned, the enforcement of insurance regulations in the United States falls almost entirely to the individual states. The lack of a powerful federal insurance authority leaves the U.S. insurance market in a fractured, and arguably chaotic, status of affairs. ${ }^{26}$ Despite the NAIC's attempt to create uniformity, none of their model laws are mandatory, and therefore are not fully adopted or enforced within the states. An insurance intermediary/producer is primarily subject to the regulations of the state their business is domiciled in.

The state Office of the Insurance Commissioner ${ }^{27}$ enforces intermediary regulations. These regulations are embedded into state statutes, or codes. According to the NAIC, 40 states have adopted the PLMA in a form which mirrors the NAIC-drafted version. However, upon closer examination, this representation is in error-a fact we will address further in the Alabama section. The ten non-adopting states have their own "related activity," which may or may not be similar to the PLMA, but upon closer examination, may also mean the state has more stringent regulations than the PLMA, i.e. California. Clearly, while the NAIC does provide a helpful list of states and their supposed adoption status, the list is only a starting point. To find the precise rules for any state, careful research is necessary. The inaccuracy of the list raises some serious doubts about how much progress the NAIC has actually made toward their goal of uniformity.

Another, equally important source of insurance intermediary law is the American common law, i.e. lawsuits handled by the courts. Generally, the state courts are tasked with interpreting the state's existing statutes. However, many states allow only the insurance commissioner to enforce the PLMA, circumventing the ability of consumers to file a lawsuit based on a violation of the PLMA, and preventing courts from enforcing the provisions. While this further weakens the effectiveness of the PLMA, it does not entirely prevent a harmed plaintiff from bringing a lawsuit against an insurance intermediary. U.S. courts also apply and interpret general principles of law such as fraud, misrepresentation, breach of contract, tortious conduct, etc.

As a result, analyzing enforcement requires a two-pronged approach, because enforcement actions can be initiated by both the state's insurance commissioner and the state courts. To understand the effectiveness of the enforcement of the insurance intermediary laws in the United States, we will look at the enforcement structures and records of three states - California, Michigan, and Alabama. These states were chosen due to their insurance sales market share-California being one of the largest

\footnotetext{
${ }^{26}$ After the economic recession of 2007-2009, an oversight body called the Federal Insurance Office was created, but it was granted only advisory powers.

${ }^{27}$ Or, Department of Insurance.
} 
markets, Michigan in the middle range, and Alabama with one of the smaller markets. $^{28}$

\subsection{California Enforcement}

California (CA) is one of the ten states that has not adopted the PMLA in a manner similar to the NAIC's recommended format. However, this is because California has detailed insurance regulations applicable to producers that date from decades before the PMLA was drafted. ${ }^{29}$ Chapter 5 of the CA Insurance Code, titled "Production Agencies" is applicable to insurance intermediaries/producers. The Code begins with more extensive and detailed definitions of relevant terms than suggested by the PLMA-most importantly of "agent" and "broker"- the two most common types of insurance intermediaries in the United States.

Section 1621 defines "insurance agent" as a "person who transacts insurance... on behalf of an admitted insurance company." An "insurance broker" is defined as "a person who, for compensation and on behalf of another person, transacts insurance. . . with, but not on behalf of, an admitted insurer." ${ }^{30}$ Whether a producer is classified as an agent or a broker will determine which regulations, and thus which penalties, are applicable to them. While these California definitions seem very clear and simple, in practice the classifications cause much confusion and lend a great deal of uncertainty to the regulations, translating into a lack of customer trust.

\subsubsection{Duties of California Insurance Intermediaries/Producers}

Article 6 of the CA Insurance Code covers "License Qualifications," and lists disqualifying factors which echo both the PMLA and the IDD, such as "lacking in integrity," knowing or willful misstatements, previous fraudulent activity or dishonesty, "incompetency or untrustworthiness," "knowing misrepresentation of an insurance policy terms or effect," failure to perform required duties, and criminal convictions. ${ }^{31}$ The CA Code goes a step further and grants the commissioner the broad power to deny an intermediary's application if "the granting of the license will be against public interest." 32 Further, licenses can be revoked if a producer has induced a client to grant them a monetary benefit such as a loan, or the inclusion of

\footnotetext{
${ }^{28}$ Property and Casualty Insurance Industry 2018 Direct Premiums Earned-California, $\$ 78.45$ billion; Michigan, $\$ 19.65$ billion; Alabama, $\$ 8.8$ billion; National Association of Insurance Commissioners 2019.

${ }^{29}$ Cal. Ins. Code $\$ \S 1621$ to 1758.994 (1959/2016).

${ }^{30} \mathrm{Cal}$. Ins. Code $\S 1623$.

${ }^{31}$ Cal. Ins. Code $\S 1668$.

${ }^{32}$ Cal. Ins. Code $\S 1668$ (b).
} 
the producer as a beneficiary in the customer's will or trust. ${ }^{33}$ There are no broad prohibitions or disclosure requirements applicable to the commissions and fees of agents or brokers in California.

\subsubsection{California Sanctions, Penalties, and Other Measures}

The California Department of Insurance's Investigation Division handles administrative enforcement, and refers crimes to local California prosecutors. Any infringement of the insurance code can lead to ordered restitution, imposed fines, and penalties. ${ }^{34}$ Administrative fines delineated by the CA Insurance Code range from $\$ 200$ to $\$ 500$. Administrative remedies also include suspension or revocation of producer licenses and cease and desist orders. Enforcement through civil courts can entail the seizure of a business, and criminal prosecution might bring incarceration, probation, and community service. Civil penalties cannot exceed $\$ 1000$ per day or per violation, up to a maximum of $\$ 50,000 .^{35}$ While these amounts might be sufficient deterrence for individual producers, they will not deter large companies. Fortunately, the Insurance Commissioner is authorized to incrementally increase these amounts with an advance notice, and larger penalties are imposed under the authorization of other California statutes and common law, which are welldeveloped in the State of California. ${ }^{36}$

The penalties which are enforced by the CA Department of Insurance are available on the Department's website, but to see them you need to search for a specific party name. This is an impediment to full transparency, as consumers are not able to compare enforcement records between the various producers and their employers, and cannot see the full breadth of investigative and enforcement work which is performed by the CA Insurance Commissioner's Investigative Division. Without a more full and effective transparency, consumers are unable to keep their representatives accountable.

\subsubsection{California Case Law}

Enforcement through civil or criminal courts can yield an almost unlimited range of potential penalties, from large monetary judgments in civil court to many years of imprisonment after a criminal trial. While the availability of strong enforcement

\footnotetext{
${ }^{33}$ Cal. Ins. Code $\S 1668.1$.

${ }^{34}$ Cal. Ins. Code $\S 1746(\mathrm{~g})$.

${ }^{35}$ Cal. Ins. Code $\S 1748.5$.

${ }^{36}$ See, for example the March 9, 2006 Marsh USA (Marsh \& McLennan Companies, Inc.) Decision and Order, which cites the California Insurance Code, criminal law, and common law principles (here, of agency) in the imposition of certain fines but an overall settlement of $\$ 100,000,000$; http:// www.insurance.ca.gov/0250-insurers/0500-legal-info/0600-decision-ruling/0100-precedential/ upload/marsh-usa-inc.pdf, last visited September 30, 2019.
} 
through the judicial system is typically viewed as a significant benefit for American consumers, under the current economic and legal circumstances it primarily results in additional uncertainty, confusion, and frustration.

First, consumers are not well-equipped to know the status of common law as it applies to insurance intermediaries. In fact, a review of precedential case law applicable to intermediaries in California yields conflicting decisions and unclear interpretations, particularly with regard to the definitions of "agent" and "broker," and defining their specific duties. The state of CA has also created a third, unusual category called "dual agency." 37 When the judiciary struggles to make bright line rules regarding the duties of intermediaries, it becomes next to impossible for a consumer to be certain of which duties are owed to them from their chosen agent or broker, and whether they have a legitimate claim of wrongdoing.

Second, California is one of the states in which the consumer does not have standing to file suit when their producer has violated the CA Insurance Code-they can only sue based on common law violations. While this may not have a significant impact when the violation is minor, because the consumer can report this to the Department of Insurance and hope they negotiate a resolution, it becomes highly problematic in the case of complex violations or ongoing patterns of dishonesty or abuse. ${ }^{38}$ Insurance commissioners do not have a proactive record of enforcing claims which require long-term, heavy investigation and evidentiary analysis. ${ }^{39}$

Finally-and the most problematic factor for U.S. common law enforcementthe judicial system is not currently a viable option for the pursuit of justice for the vast majority of Americans. Lawsuits have become too expensive to be maintained by all but the very wealthiest of American citizens, and the alternatives of mediation or arbitration are also prohibitively expensive. ${ }^{40}$

\subsubsection{California Enforcement Summary}

Although California should be commended for its very detailed and well-thought insurance code, the resulting enforcement lacks in (1) transparency, (2) deterrence, and (3) breadth, because (a) it does not address or aid prosecution of common law violations, which are a fundamental, critical judicial balance and support to U.S. legislation, (b) the commissioner is not proactively enforcing all legislative acts, and particularly not those which cover repeated and widespread patterns of abuse, and (c) the insurance code cannot be enforced through private lawsuits.

\footnotetext{
${ }^{37}$ U.S. Fidelity \& Guar. Co. (2008) at 1122-23.

${ }^{38}$ Particularly those which are covered by the Unfair Trade Practices Act (which applies to producers) or the Unfair Claims Settlement Practices Act (which can implicate producers) - both drafted by the NAIC and adopted by the state of California.

${ }^{39}$ Defever (2018), p. 17.

${ }^{40}$ Defever (2018), p. 17.
} 


\subsection{Michigan Enforcement}

Michigan (MI) is one of the 40 states that is listed as having adopted the PMLA in a manner similar to the NAIC's recommended format. Chapter 12 of the MI Insurance Code, titled "Agents, Solicitors, Adjusters, and Counselors" is applicable to insurance intermediaries/producers. ${ }^{41}$ The state of Michigan uses different definitions than both California and the PLMA. While the PLMA does not attempt to define the different types of producers, and CA goes an extra step and delineates definitions for both agents and brokers - the state of Michigan takes a different approach altogether and defines an "agent" as "an insurance producer." Agents are then further broken down into the subsections "agent of the insured" and "agent of the insurer".

The word broker appears never to be used in the context of insurance sales in Michigan-all insurance sales and negotiations are performed by agents. However, there is an additional status of "solicitor". A solicitor works for a licensed agent/ producer, and "may solicit applications for insurance and collect premiums on behalf of a licensed insurance producer resident. . if he or she is so authorized to act by a written contract with the insurance producer, the contract specifies the extent of his or her authority to act, he or she is licensed to act as a solicitor... and the insurance producer has notified the director ${ }^{42}$ of the contract." 43 There are also specific rules regarding how an agent for the insured and an agent for the insurer are allowed to contract. An agent of the insured may only obtain coverage for a customer through an agent of the insurer if "the agent of the insured has a relationship with the agent of the insurer under a written contract. . [which] must specify the extent of the agent of the insured's authority to act and require the maintenance of an amount of professional liability insurance. ..".44

The State of Michigan also licenses "insurance counselors," which are defined as those who "provide advice, counsel, or opinion with respect to benefits promised, coverage afforded, terms, value, effect, advantages, or disadvantages of a policy of insurance. ..". ${ }^{45}$ It is unclear exactly how counselors differ from agents, but the code section does mention that the definition of counselor is not meant to prohibit the customary advice offered by a licensed insurance agent.

If one compares these Michigan-defined relationships with the defined relationships of agent and broker in California, as well as the usage of the terms "intermediary" and "distributor" in the IDD (which does also utilize the words broker and agent), it is easy to understand why uniformity is a high priority on both continents. If the regulators and experts struggle to keep track of basic terms, how can we ever expect customers to feel confident?

\footnotetext{
${ }^{41}$ M.C.L.A. $\$ \$ 500.1201$ to 500.1247.

${ }^{42}$ Director refers to Michigan's director of licensing.

${ }^{43}$ M.C.L.A. $\$ 500.1211$ (1) "Contract requirements for solicitor and agent of insured".

${ }^{44}$ M.C.L.A. § 500.1211 (2).

${ }^{45}$ M.C.L.A. § 500.1232.
} 


\subsubsection{Duties of Michigan Insurance Intermediaries/Producers}

The license qualifications for Michigan insurance solicitors and consultants are more specific than the role of an agent, and appear quite thorough. While all three roles require education and training, the solicitors and consultants also are investigated by the insurance commissioner to ensure they have a reasonable understanding of the insurance products and state insurance laws, intend to act in good faith, are honest and trustworthy, and possess a good business reputation and good moral character. ${ }^{46}$ These standards appear to generally echo the California license qualifications, only the terminology is much broader and leaves a great deal more discretion to the insurance commissioner.

Solicitors are also required to act as a fiduciary for all monies received or held in their capacity as a solicitor, and are not allowed to pay referral fees or any type of commission to someone who procures business for them. ${ }^{47}$ Consultants are not fiduciaries, but they must disclose their fee to the customer, and if they are receiving a commission from an insurer when they act as an agent to procure coverage, they must disclose that commission. Again, these are interesting qualifications in that they seem to partly mirror the IDD and partly the CA requirements.

Licensed insurance producers are subject to penalties if they "violate any insurance laws or regulation. .."; attempt to obtain a license through misrepresentation or fraud; improperly withhold or convert any money received in the course of business; intentionally misrepresent insurance terms have committed any insurance unfair trade practice or fraud; use fraudulent, coercive, or dishonest practices; or demonstrate incompetence, untrustworthiness, or financial irresponsibility in the conduct of business. ${ }^{48}$ These requirements are a close replica of Section 12 of the PLMA. The regular use of commissions and service fees in Michigan are not directly addressed, but implicitly authorized. ${ }^{49}$

\subsubsection{Michigan Sanctions, Penalties, and Other Measures}

The penalties for violations of the insurance code in Michigan range from merely license revocation and cease and desist orders to civil fines or restitution for the injured. Unlike California, no criminal prosecution is mentioned. Civil fines cannot be more than $\$ 1000$ for each violation, unless the violator knew or reasonably should have known of their violation - then the commissioner can impose up to $\$ 5000$ per violation. No combination of fines can exceed $\$ 50,000$. Civil fines are also imposed if a person knowingly violates a cease and desist order-no more than $\$ 20,000$ for

\footnotetext{
${ }^{46}$ M.C.L.A. $\S 500.1214(3)$ and M.C.L.A. $\S 500.1234(3)$.

${ }^{47}$ M.C.L.A. $\$ 500.1216$.

${ }^{48}$ M.C.L.A. § 500.1239 (1).

${ }^{49}$ See M.C.L.A. $\$ 500.1240$ which explains that commissions and fees are forbidden when the producer is unlicensed.
} 
each violation, and no more than a total of $\$ 100,000 .^{50}$ These monetary penalties are similar to the civil fines available under the CA Insurance Code.

Restitution for the insured is available to cover incurred losses, damages, or other harm, and no monetary limit is provided. The commissioner can also require a refund of any overcharges. The unlimited availability of restitution is relatively comparable to the IDD's allowance for the penalty of up to twice the amount of the profits gained, or losses avoided, because of the violator's breach. ${ }^{51}$ However, the specifically delineated civil penalties of both Michigan and California are incredibly small compared to the IDD's limits in the hundred of thousands, or several million, euros.

Despite the low penalties, the State of Michigan is doing an excellent job with transparency of insurance code enforcement. Every quarter they publish a detailed, web searchable enforcement report in PDF format which lists all enforcement actions taken. A clear table with descriptive headers is used, indicating the name of the violator, their case number, the type of license or registration, the date of the commission's action, the specific action taken, the reason for the action, the type of file closure used, the date of file closure, and the fines and penalties imposed. Some examples of the "reason[s] for action" are "Misconduct of Business, M.C.L $\S$ 500.1239(1)(d)" and "Unlawful Behavior of an Agent, M.C.L. 500.1239(1)(b)(e)". The specific citation of the legal clause used for enforcement is unambiguous. Fines and penalties range from "Revoke License" to " $\$ 8,000$ Civil Penalty.", To be fair, California's database of violators did provide links to the actual legal documents which support the penalty imposed, but again, that is only if you already know the name of the violator. The Michigan approach is much clearer and easy to navigatemuch more consumer-friendly.

\subsubsection{Michigan Case Law}

Like California case law, Michigan case law struggles with a lack of clarity. Also like California, the definitions of agent and broker are raised in Michigan courts, which is interesting given that the word "broker" never appears in the Michigan insurance statutes. ${ }^{53}$ For an insurance consumer, this will be utterly confusing.

Overall, the status of insurance case law in the United States is in a conflicted and confusing state. A reading of the chapters "Negligence Claims by Insureds" and "Broker Liability" in the treatise Law of Commercial Insurance Agents and Brokers reveals that some state courts assert that customers cannot be expected to know the requirements of proper care applicable to agents or brokers, ${ }^{54}$ but that other state

\footnotetext{
${ }^{50}$ M.C.L.A. § 500.1244.

${ }^{51}$ IDD Art. 33, 1. (f) (ii).

${ }^{52}$ See https://www.michigan.gov/difs/0,5269,7-303-20594_46950\%2D\%2D-,00.html, last visited September 29, 2019.

${ }^{53}$ Cleveland Indians Baseball Co. v. New Hampshire Ins. Co., (2013) at 640.

${ }^{54}$ Todd v. Malafronte, (1984) at 466.
} 
courts believe that insurance "is not a field that is so highly technical that the public cannot understand at least the general nature of an agent's responsibilities." some courts only require expert testimony regarding the duties of agents and brokers when the insurance claims are complex, California requires expert testimony regarding these duties because "the standard of care is beyond the common knowledge of the layperson". 56

U.S. states clearly do not agree on the basic elements of insurance law. The common law system supplies very little support for the insurance codes-sometimes even undermining or confusing them by introducing additional concepts like dual agency in California, or the undefined role of broker in Michigan.

\subsubsection{Michigan Enforcement Summary}

Michigan is doing an admirable job with enforcements and transparency. A review of their quarterly enforcement summaries reveals a great deal of activity investigating and penalizing offenders. However, the penalties could certainly be higher, particularly in the case of legal persons, i.e. companies. Penalties which have a maximum of $\$ 100,000$ will not be effective deterrence to large companies. Also, if the commissioner is merely ordering the intermediary to return the improper gain, but not adding a large amount of restitution, the intermediary may not hesitate to attempt to cheat the laws again. Fortunately, although the penalties have very low caps, there are clauses like the one allowing restitution which allow additional amounts to be added.

\subsection{Alabama Enforcement}

The NAIC also lists Alabama as a state which has adopted the PLMA in a substantially similar manner, but upon further research, this is potentially misleading. The NAIC lists Chapter 7 of the Alabama Insurance Code as the PLMA "Model adoption." However, from 1991 to 2013, Alabama has repealed 19 of the 61 sections in Chapter 7. While it would be difficult to tell if the repealed sections were accurate and/or essential matches of the PLMA, there is a demonstrated lack of substance in Alabama's Insurance Code.

Alabama adds yet another mix of insurance terms to our pool - using primarily the words "producer" and "service representative". There is no mention of brokers,

\footnotetext{
${ }^{55}$ Atwater Creamery Co. v. Western Nat. Mut. Ins. Co., (1985) at 279.

${ }^{56}$ Law of Commercial Agents \& Brokers, Chapter 2 - Negligence Claims by Insureds (2017 Supplement) at 57.
} 
consultants, solicitors, or distributors. ${ }^{57}$ Agents are mentioned, but not defined or singled out as subject to the code. The term producer is defined as "a person required to be licensed under the laws of this state to sell, solicit, or negotiate insurance." A service representative is defined as "a natural person, other than an officer, manager, or managing general agent of the insurer, employed on salary... by the insurer [or] managing general agent... to work for... producers in selling, soliciting, or negotiating insurance in the insurer. . ., but only in the property lines of authority." 58

When compared with the definitions of the IDD, California, and Michigan, the closest matches we have for the Alabama definition of producer are "insurer's agent" or perhaps "solicitor" in Michigan, or simply "agent" in California. Service Representatives appear to be merely employees of Alabama producers, but more highly regulated than they would be in other states. Also, the use of the word agent to describe the employer of the service representative adds another layer of confusion.

PLMA adoption has failed to provide consistency amongst basic insurance terms. This failure results in each state regulating completely different actors who perform entirely different scopes of activity, and with different regulatory methods.

\subsubsection{Duties of Alabama Insurance Intermediaries/Producers}

The duties of Alabama "licensees," as they are called, are very similar to those of licensed Michigan producers, which in turn echo the suggested terms of Section 12 of the PLMA. ${ }^{59}$ The only significant standout is a clause authorizing a penalty when a licensee induces, persuades, or advises "any policyholder to surrender or cause to be cancelled any policy of insurance issued to the policyholder by any authorized insurer in exchange for a policy offered by the licensee where the surrender or cancellation shall result to the financial detriment of the policyholder." ${ }^{\text {" }}$ While most of Section 12 of the PLMA is quite broad, this is an example of Alabama adopting those recommended general clauses, but then adding the state's own, more specific and narrow regulation. Unfortunately, this is the only notable example of the Alabama legislature doing so. However, the Michigan and Alabama adoption of Article 12 indicate that the PLMA has assisted in some uniformity, even if with that one article, only.

Like Michigan and California, Alabama requires education and training for their equivalents of intermediaries/producers. They also require fingerprinting and a criminal history check. ${ }^{61}$ If a license applicant has been convicted of a felony, a review committee considers multiple factors before making a recommendation to the

\footnotetext{
${ }^{57}$ Brokers and Solicitors appear to have been mentioned in the Repealed sections, but these have not been replaced.

${ }^{58}$ Ala. Code 1975 § 27-7-1 (5) and (20).

${ }^{59} \mathrm{See}$ the last paragraph of section 4.2.1.

${ }^{60}$ Ala Code 1975 § 27-7-19(6).

${ }^{61}$ Ala. Code 1975 § 27-7-4.4 and § 27-7-5.
} 
Commissioner regarding approval or disapproval of the application. The factors are reminiscent of the factors prescribed in IDD Article $34^{62}$ to be considered before applying sanctions to intermediaries who violate the law, only here, they are used to screen for the degree of criminality of a potential licensee. For example, the Alabama Review Committee considers (among others) the following factors: the nature and severity of the offense(s); the particular circumstances of the offense(s); the nature and extent of injury or loss to other persons or property; whether the offense(s) are related to insurance; the sentence imposed; the time that has elapsed since the conviction or sentence; any aggravating or mitigating factors; and any relevant evidence tending to demonstrate contrition or rehabilitation. ${ }^{63}$ Where the state of Alabama will allow those with criminal pasts a chance to work as an insurance intermediary, the EU Commission is revoking the licenses of - and placing very large sanctions upon-those very same individuals.

Monetary commissions are allowed in Alabama, with some restrictions. Licensees are not allowed to share their commissions unless they are a producer sharing with other licensed producers for the same kinds of insurance or insurance classifications. ${ }^{64}$ Producers seem to have a fiduciary duty of some degree, as they are required to keep premiums and funds being held for others in a trust fund, "in a fiduciary capacity", 65

\subsubsection{Alabama Sanctions, Penalties, and Other Measures}

Alabama fines an unlicensed "person who sells, solicits, or negotiates insurance" with a fine up to three times the premium received. ${ }^{66}$ A similar penalty applies to an insurer or producer who pays "any commission or other valuable consideration to a person for services as a producer or service representative" who is unlicensed (three times the commission paid). ${ }^{67}$ If a producer or service representative submits a false or fraudulent application for license renewal, the license can be suspended or the licensee "may be subject to a civil fine in an amount not to exceed $\$ 10,000$.

The penalties for "licensees" violating the provisions of $\S 27-7-19$ (echoing Article 12 of the PLMA) are license suspension, probation, revocation, and/or a civil fine in an amount not to exceed $\$ 10,000$ per violation. There is no overall cap on fines, so if there are multiple violations the fines can add up significantly. ${ }^{68}$

Alabama does post an "Annual Fraud Bureau Report" from the previous year, on the Department of Insurance website. However, the report is a short, five-page PDF

\footnotetext{
${ }^{62}$ See last para., section 3.3 herein.

${ }^{63}$ Ala. Admin. Code $\$ 482-1-146-.07$.

${ }^{64}$ Ala. Code 1975 § 27-7-35.

${ }^{65}$ Ala. Code 1975 § 27-7-36.

${ }^{66}$ Ala. Code 1975 § 27-7-4 and § 27-7-35.1.

${ }^{67}$ Ala. Code 1975 § 27-7-4.1 and § 27-7-35.1.

${ }^{68}$ Ala. Code 1975 § 27-7-19 (b) and (c).
} 
document containing some generalizations regarding the results of the different investigations, such as "unfounded," "lack of resources," and "presented for prosecution". There is no additional information about the investigations-not the nature of the violation, not the name of the offender, not the code provision at issue, no list of penalties... nothing additional. Alabama's enforcement is completely lacking in transparency, to the great detriment of consumers.

\subsubsection{Alabama Case Law}

Alabama courts offer little to no interpretive support for the Alabama insurance code chapter applicable to producers. As discussed in the California and Michigan sections, this is unfortunate because (1) the state codes are not exhaustive and would benefit from clarification and supplementation, most particularly the sparse Alabama code, and (2) the overall lack of litigation by harmed consumers is a direct result of the exorbitant costs of American lawsuits.

\subsubsection{Alabama Enforcement Summary}

Alabama's use of penalties that are multiples of the amount illegally received is similar to the IDD penalties of Article 33 prescribing sanctions up to two times the profits gained. These style penalties are effective because they ensure not only the illegal profit is taken away, but a proportional punishment is imposed. While Alabama seems to have some basic penalties in place, the lack of publication of enforcement activities renders it is impossible to know if the insurance code is being enforced sufficiently.

\section{Structures for Enforcement in the United States and the European Union}

As we can see, the enforcement structures of the U.S. and the EU are very different. In the United States, federal law has very little cohesive effect, due to the federal government declining to use its powers to legislate insurance law. Regulation falls to the individual states, where a combination of state statutes and court-created common law comprise the body of insurance regulations. The state insurance commissioners collectively meet as the National Association of Insurance Commissioners and draft advisory acts like the PMLA which the states can elect to adopt and use as they choose. However, the nature of these advisory acts renders them principlesbased in a similar fashion to the IDD's predecessor the IMD, and we can see through 
these examples that principles-based regulations are not able to support effective enforcement. $^{69}$

In the EU, the equivalents of the U.S. federal law are the Directives promulgated by the Commission of the European Union. The Commission has authored several mandatory acts regulating the business of insurance, most recently the IDD. Member States are required to adopt the IDD and integrate it into their individual state insurance law regimes. As the Commission issues new Directives and updates the previous ones, the regulations are shifting away from their principles-based origins and becoming more rules-based. This shift will have a major impact on the enforcement mechanisms of the Member States because while principles-based regulations rely on self-enforcement by the actors, rules-based regulations require the Member States to enforce specific rules.

\section{What Can Member States Learn from the Enforcement Failures of the United States?}

The primary difference between the IDD and the PLMA is that the IDD is mandatory and the PLMA is voluntary. Due to its advisory nature, the PMLA has been inconsistently adopted and inconsistently enforced. As we discovered through our analysis of three very different states, California, Michigan, and Alabama, even in the instances where the basic principles of an article in the PMLA are adopted, they are significantly altered to suit the individual state's perceived needs. The bodies of regulations applying to insurance producers remain in a piecemeal state, and the PMLA has done very little to close the gaps. Even in the event that the PMLA was uniformly adopted in all 50 states, the incredible differences in the state enforcement regimes would still lend uncertainty, uneven application, and inconsistent results.

The takeaway for EU Member States should be that uniformity will not be achieved until and unless they adopt and apply the mandatory penalties provided in the IDD, and achieve a sufficient level of transparency to aid consumers in avoiding bad actors, and act as a deterrence to producers. The IDD's more prescriptive, rules-based insurance regulations will be the first of their kind to be applied across such a wide and diverse territory as the EU Member States. Insurance scholars are voicing concern that the IDD has taken the new regulations a step too far, and the immense costs of complying with the minimum harmonizations will be crippling to the Member States and cause damage the insurance economy. ${ }^{70}$ However, as can be seen in the U.S. example, stricter rules are needed for the protection of consumers and the health of the insurance market.

\footnotetext{
${ }^{69}$ See Ferran, Ellis, Regulatory Lessons from the Payment Protection Insurance Mis-selling Scandal in the UK (2012) for analysis of this phenomena as it occurred in the UK.

${ }^{70}$ See De Maesschalck (2017); See Hofmann et al. (2018).
} 
Despite the cultural homogeneity of the U.S. states, insurance regulations remain principle-based and uniformity of enforcement under the current regime has widely failed. As the EU moves forward with the IDD, it is now the United States that should be asking what can be learned from the EU's inevitable failures and successes in the application of the IDD. ${ }^{71}$

\section{References}

Alabama Administrative Code $\S 482-1-146-.07$

Alabama Insurance Code 1975 § 27-7-1 to § 27-7-44

Atwater Creamery Company v. Western National Mutual Insurance Company, 366 N.W.2d 271, 279 (Minn. 1985)

California Insurance Code $\S \S 1621$ to 1758.994 (1959/2016)

Cleveland Indians Baseball Company., L.P. v. New Hampshire Ins. Co., 727 F.3d 633, 640 (6th Cir. 2013) (Michigan law)

De Maesschalck N (2017) The Insurance Distribution Directive: what does it change for intermediaries and for others? In: Marano P, Siri M (eds) Insurance regulation in the European Union. Palgrave Macmillan, pp 59-77

Defever KM (2018) Comparative analysis of European Union and United States insurance law systems - with emphasis on consumer protection law. Eur J Commer Contract Law (Paris Legal Publishers) 2018-2/3:9-27

Directive (EU) 2002/92/EC of the European Parliament and of the Council of 9 December 2002 on insurance mediation

Directive (EU) 2016/97 of the European Parliament and of the Council of 20 January 2016 on insurance distribution

Ferran E (2012) Regulatory lessons from the payment protection insurance Mis-selling scandal in the UK. Eur Bus Org Law Rev (Cambridge University Press) 13(2):247-270

Gibbons v. Ogden, 22 U.S. 1 (1824)

Hofmann A, Neumann JK, Pooser D (2018) Plea for uniform regulation and challenges of implementing the new Insurance Distribution Directive. The Geneva Papers, Palgrave Macmillan, pp 740-769

In the Matter of the Licenses and Licensing Rights of Marsh USA, Inc., d.b.a. Marsh Risk and Insurance Services, et al., Decision and Order of the Insurance Commissioner of the State of California, March 9, 2006

Michigan Compiled Laws, $\S 500.1201$ to 500.1247 (1980/2018)

Producer Licensing Model Act (2005) National Association of Insurance Commissioners

Pscheidl D (2018) Implementing IDD across the EU - first findings and the way forward. ERA Forum 19:205-217

Todd v. Malafronte, 3 Conn. App. 16, 484 A.2d 463, 466 (1984)

U.S. Fidelity \& Guarantee Company v. Lee Investments LLC, 551 F. Supp. 2d 1114, 1122-23 (E.D. Cal. 2008)

Unfair Claims Settlement Practices Act (1997) National Association of Insurance Commissioners Unfair Trade Practices Act (2004) National Association of Insurance Commissioners

United States v. South-Eastern Underwriters Association, 322 U.S. 533 (1944)

\footnotetext{
${ }^{71}$ See Hofmann et al. (2018) for the same conclusion after a detailed comparison and analysis of EU and U.S. insurance distribution regulations.
} 
Viscusi WK (2002) Regulation through Litigation, AEI-Brookings Joint Center for Regulatory Studies

Weimer, BD Hagglund CE, Whitman AF (2017) Law of commercial insurance agents and brokers. Thomson West

15 U.S.C. $\$ 1012(b)$

Open Access This chapter is licensed under the terms of the Creative Commons Attribution 4.0 International License (http://creativecommons.org/licenses/by/4.0/), which permits use, sharing, adaptation, distribution and reproduction in any medium or format, as long as you give appropriate credit to the original author(s) and the source, provide a link to the Creative Commons licence and indicate if changes were made.

The images or other third party material in this chapter are included in the chapter's Creative Commons licence, unless indicated otherwise in a credit line to the material. If material is not included in the chapter's Creative Commons licence and your intended use is not permitted by statutory regulation or exceeds the permitted use, you will need to obtain permission directly from the copyright holder. 